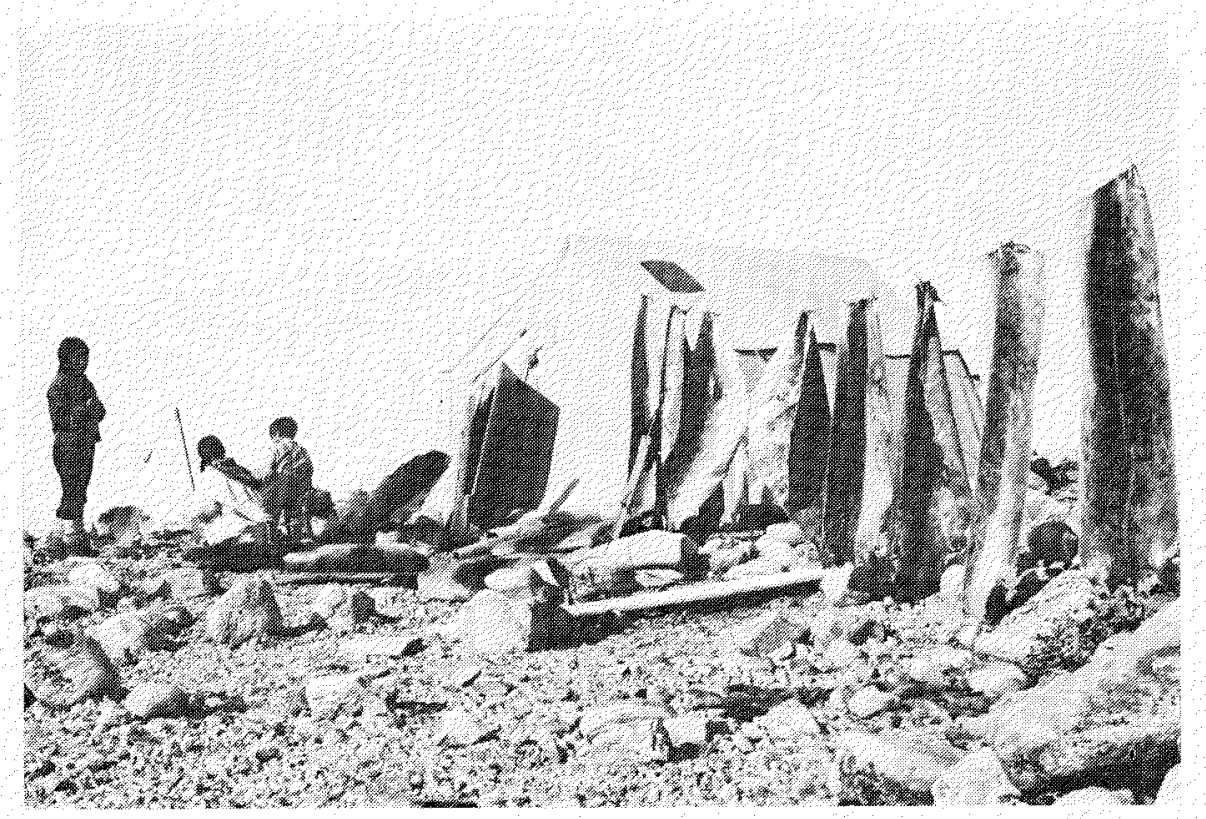

Preparing ringed-seal skins at summer camp, Eglinton Fiord, Baffin Island. 


\section{The Harp-seal Controversy and the Inuit Economy}

\section{GEORGE WENZEL 1}

At a time when the economy and culture of Canada's Inuit are coming under increasing strain as a result of the penetration of southern ways of life into the North, a second potential threat to them has also arisen from environmentalactivist groups opposed to the northwest-Atlantic seal hunt. Just over ten years ago, D.C. Foote called attention to the effects protests directed at the Gulf of St. Lawrence harp-seal hunt were having on the local economies of Inuit communities in the eastern Arctic. In a brief note (Foote 1967), he pointed out the close economic and cultural relationship between the Inuit and the ringed seal. By the end of the nineteen-sixties, the intensity of the protest had diminished and the market for ringed seals stabilized.

Until 1977, little more was heard from the protesters. Then the controversy surrounding the organized hunting of newborn harp seals by Canadian and foreign sealers in the Gulf of St. Lawrence again arose. Several organizations located in southern Canada began an intensive publicity campaign to have the hunt banned. The form which the protests has taken is well known, for it has been given widespread coverage by the news media in both North America and Europe. However, while this campaign has had, at best, only a moderate effect on the commercial exploitation of harp seals, it has had far greater repercussions on the economy of the Canadian Inuit.

Over much of the eastern Arctic (roughly from Coronation Gulf to Labrador), Inuit communities are heavily dependent on the ringed seal (Phoca hispida) which constitutes the primary local food resource of many of their settlements, as it is a year-round Arctic resident and one of the most numerous pinnipeds in Canadian waters. Furthermore, the sale of the skins of ringed seals has traditionally provided, and continues to provide, a significant portion of the cash income of many Inuit. By contrast, the harp seal (Pagophilus groenlandicus) is present in northern waters only during the short summer, after the pups of the species have been born off the Labrador-Newfoundland coast. In economic terms, therefore, the harvesting of harp seals accounts for only a small fraction of the cash income of most Inuit communities. Furthermore, only some three per cent of the seals taken in the North are harp seals.

The role of the ringed seal in Inuit economic and social life has been the subject of repeated documentation, ever since Europeans first encountered the Inuit. During the nineteenth century, many European explorers left records which provide an indication of the economic importance of ringed seals in traditional Inuit society. It was Boas (1888) however, in an analysis of Inuit winter settlement patterns, who first demonstrated the close ecological relationship between Inuit and ringed seal. Members of the Fifth Thule Expedition (Degerb $\varnothing 1$ and Freuchen 1935) extensively documented the utilization of ringed seals in the Hudson Bay - Foxe Basin - North Baffin area during the early twentieth century, but found little evidence of the use of harp seals.

1Department of Geography, McGill University, Montreal, Quebec, Canada 
The importance of the ringed seal to the Inuit extends beyond the economic into socio-cultural relationships. Rasmussen (1931), Van de Velde (1956) and Damas (1972) have all described the complex patterns of social behaviour existing among the Inuit of the eastern Arctic in regard to the sharing of seal meat - their subsistence staple. More recent research (e.g. Wenzel 1975) has shown the special role these behaviour patterns play in the reinforcement of group bonds.

The hunting of harp seals, on the other hand, does not have a very long tradition among the Inuit, because of the obstacles that existed to approaching this species prior to the introduction of the rifle and motor-powered boat. It is only since the era between the two world wars that harp-seal hunting by the Inuit has acquired any degree of importance, and this only in a few communities in Labrador, Baffin Island and the High Arctic. It has in fact always been concentrated in the Newfoundland - Gulf of St. Lawrence area where there is easy access to the whelping grounds from land as well as sea (Sergeant 1976 p. 97). Historically, sealing in this area was begun by Algonkian aborigines in pre-Columbian times and was later continued by French and British colonists. The present commercial hunt originated in the nineteen-thirties, when Norwegian hunters moved from the depleted hunting grounds of the White Sea, to which access was anyway prohibited by the Soviet government shortly after the Second World War (Sergeant 1976 p. 102). Thereafter, those who participated in the Newfoundland and Gulf hunts included land-based hunters, and Canadian and Norwegian commercial sealers. Formal regulation of the hunt by the Government of Canada was instituted in the late nineteen-fifties, and the present quota and target systems were established in 1972 (Sergeant 1976 p. 113).

While the object of the protesters over the last fifteen years has been to ban the Newfoundland and Gulf hunts, their campaign, because of its very general and emotional nature (Davies 1970; Bardot 1977), has had its greatest impact on the ringed-seal market. This becomes evident when economic data relating to Inuit ringed-seal harvesting for 1977 are compared to those for 1971-74. Foote (1967 p. 267) noted that the price of mature ringed-seal hides rose from $\$ 1.50$ in 1955 to $\$ 12.25$ in 1963 , while that of exceptionally fine skins and the pelts of immature animals was closer to $\$ 20.00$. In 1967 , at the height of the first outcry, market prices dropped to $\$ 2.50$ per hide, at which they were artificially stabilized by the Hudson's Bay Company.

By 1971, the price for ringed-seal pelts had again risen throughout the eastern Arctic. In that year, the price at Chesterfield Inlet was $\$ 13.00$ and, from 1971 through 1974, that at Clyde River averaged $\$ 14.00$ for an annual harvest of 1,000-1,500 seals (author's field notes). Following the 1977 protest, however, a downward trend became apparent in the demand for ringed-seal hides. In June, the price stood at $\$ 14.00$, but by August had fallen to $\$ 10.00$; in November, the price in the eastern Keewatin was just below $\$ 1.00$, while in northern Quebec it stood at $\$ 1.25$. These prices are the lowest received by Inuit hunters of the ringed seal since the early nineteen-fifties. A corresponding decline in prices was reported from communities on Baffin Island and other parts of the Arctic. 
This trend, if it continues, has several serious implications for the socioeconomic base of many small local Inuit communities and for individuals in larger centres who prefer the life of a hunter to that of a labourer. First, since 1967, when Foote voiced his concern, the Inuit in their hunting have become even more dependent on expensive, imported equipment. Up to the late nineteen-sixties, dog traction still remained a major means of winter travel over much of the North, while rifles, ammunition, boats and fuel were available to Inuit at prices far below those of the present (see Table 1). By 1972, the snowmobile had replaced the dog team in all but a few settlements and camps. As is indicated in Table 1, the cost to hunters of certain items of basic equipment in 1976-77 was substantially above that four years earlier. At the same time, it should be noted that other important items such as fuel and spare parts are not taken account of in Table 1. Even so, the listing shows that the cost of hunting to the Inuit has increased by $50 \%$ or more. And in 1977 these increases in cost have been accompanied by a fall in the prices obtainable for the ringedseal pelts themselves.

This decline in prices poses a threat, not only to sealing by the Inuit but to all types of subsistence hunting by them as well. In most communities, as Schaefer (1971) has emphasized, the food provided by marine mammals caribou, fish and birds - is vital for the nutritional health of the Inuit. (In any case, outside of the largest northern communities, such as Frobisher Bay and Inuvik, many southern substitute meats, which have lower protein and fat content, are not even available.) Purely subsistence activities often entail a greater expenditure on equipment and fuel than does sealing done mainly with the market in view. Thus, while the ringed seal supplies a food as well as a marketable commodity, it is as the latter that it supports other forms of Inuit subsistence activity. The hunting of certain animals, such as polar bear and narwhal, whose skins are marketable, is restricted by government quota. Members of Inuit communities may, as a result of these factors, have no other choice but to abandon hunting, despite the consequences for themselves and their families in terms of health and traditional culture.

TABLE 1. Costs of equipment for hunting in 1972-73 and 1976-77.

\begin{tabular}{lcc}
\hline \multicolumn{1}{c}{ Item } & $\begin{array}{c}1972-73 \\
\text { (dollars) }\end{array}$ & $\begin{array}{c}1976-77 \\
\text { (dollars) }\end{array}$ \\
\hline Snowmobile & $1,400.00$ & $2,500.00$ \\
Snowmobile engine & - & 830.00 \\
Trail motorcycle $(50 \mathrm{cc}$ ) & - & $1,150.00$ \\
Outboard motor $(25$ H.P.) & 900.00 & $1,100.00$ \\
22-foot $(6.7-m)$ canoe & $1,200.00$ & $1,800.00$ \\
303 Enfield rifle & 99.00 & 150.00 \\
.222 Remington riffe & 150.00 & 249.95 \\
.22 semi-automatic rifle & 60.00 & 72.95 \\
20 shells for .303 rifle & 7.00 & 9.98 \\
20 shells for .222 rifle & 5.00 & 7.58 \\
20 shells for 12-gauge shotgun & 9.00 & 11.00 \\
Fox trap & 1.00 & 2.49 \\
Duffle (for winter clothing) & $8.75 /$ metre & $13.11 /$ metre \\
\hline
\end{tabular}


While it is not yet possible to claim a direct causal link between the protests heard outside the North and the decline of the ringed-seal market, it is already evident that the uncompromising approach of the opponents of the Newfoundland-Gulf seal hunt is having an unsettling effect. The European finefur market, into which the bulk of the harp-seal skins from the northwestern Atlantic pass, has remained fairly stable in terms of prices for "white-coats" (from harp-seal pups) and "bluebacks" (from hooded-seal pups). The rough-fur (ringed-seal) market is, however, depressed, and the concern which the Inuit feel about the situation was made known to the Canadian government, in November 1977, by the Inuit Tapirisat of Canada.

A number of observers in southern Canada, including members of the government's fishery service, have stated that the low demand for ringed seal is a result of a change in fashion. Recent events, however, appear to be in conflict with such a view; although ringed-seal pelts offered at the most recent Canadian fur auction had to be withdrawn, the Hudson's Bay Company was able to sell the greater part of its ringed-seal product in Europe early in 1978 at a price near its former level.

Notwithstanding the recent upswing of prices for ringed-seal pelts in Europe, the immediate question is whether the market will recover sufficiently to benefit Inuit hunters, for the impact of the current (spring 1978) round of protests has not yet been felt. Given the present situation, one point must be emphasized: that the protest - despite the fact that it is a means of drawing attention to a possibly endangered species - can only adversely affect what is the basis of the local native economy in the North, if a distinction between Inuit subsistence activities and the Newfoundland-Gulf commercial hunt is not clearly drawn. This economy, which up to the present has been remarkably resilient in the face of the activities of fur traders and exploration for oil and gas - and, at times, government misunderstanding - might prove less able to withstand undiscriminating public protest.

\section{REFERENCES}

BARDOT, B. 1977. A Labrador Journal. Vancouver, British Columbia: Greenpeace Foundation (Greenpeace Chronicles no. 5). pp. 10-11.

BOAS, F. 1888. The Central Eskimo. Washington, D.C.: Bureau of American Ethnology (Annual Report no. 6). pp. 409-699.

DAMAS, D. 1972. Central Eskimo systems of food sharing. Ethnology, 11(3):220-40.

DAvIES, B. 1970. Savage Luxury: The Slaughter of the Baby Seals. London: Souvenir Press. DEGERB $\emptyset \mathrm{L}, \mathrm{M}$. and FREUCHEN, P. 1935. Mammals. Report of the Fifth Thule Expedition, 1921-24, Vol. 2, Parts 4 and 5. Copenhagen: Gyldendal. pp. 195-219.

Foote, D.c. 1967. Remarks on Eskimo sealing and the harp seal controversy. Arctic, 20(4):267-8.

RASMUSSEN, K. 1931. The Netsilik Eskimo: social life and spiritual culture. Report of the Fifth Thule Expedition, 1921-24, Vol. 8, Nos. 1 and 2. Copenhagen: Gyldendal.

SCHAEFER, o. 1971. When the Eskimo comes to town. Nutrition Today, 6(6):8-16.

SERGEANT, D.E. 1976. History and present status of populations of harp and hooded seals. Biological Conservation, 10(2):95-118.

VAN DE VELDE, F. 1956. Rules governing the sharing of seal after the "Aglus" hunt among the Arviligjuarmiut. Eskimo, 41:3-6.

WENZEL, G. 1975. The ecology of Inuit hunting at Clyde River, eastern Baffin Island. (Unpublished report on file at the National Museum of Man, Ottawa, Canada.) 